\title{
Penerapan Metode PDCA Dalam Peningkatan Kualitas Pada Product Swift Run di PT. Panarub Industry
}

\section{Application of PDCA Method for Quality Improvement in Swift Run Product at PT. Panarub Industry}

\author{
Nur Fadilah Fatma ${ }^{1}$, Henri Ponda ${ }^{2}$, Paras Handayani ${ }^{3}$ \\ 1,2. Program Studi Teknik Industri, Fakultas Teknik, Universitas Muhammadiyah Tangerang \\ ․ㅡurfadilah.fatma@umt.ac.id,
}

\begin{abstract}
To produce products of good quality in the current era of globalization, an industry is required to provide products that are not defective and in accordance with specifications. PT. Panarub Industry is a shoe making industry with a variety of models. In the production process, PT. Panarub Industry carries out quality control by setting a maximum damage tolerance limit of 5\%. However, in controlling the quality, there are still defective products. The percentage is above the tolerance limit of $80 \%$, among others are Shoes that are not Bonded or Open Bond $77.81 \%$, gross $12.58 \%$, Overload Assembly 9.25\% and tilted 0.36\%. The root causes of the problems in the quality of the Swift Run model shoes include human factors, namely employees who are less competent and do not understand SOP, material factors, which are declining quality of raw materials and do not use the FIFO system in the material storage space and machine factors, namely lack of scheduling and checking. the machine at regular intervals, which causes the engine to often experience damage and dirty engine conditions.
\end{abstract}

Keywords: Quality, PDCA, 5W1H, Predator Shoes 18.3 FG, Defect

\begin{abstract}
ABSTRAK
Untuk menghasilkan produk dengan kualitas yang baik pada era globalisasi saat ini, sebuah industri dituntut untuk memberikan produk yang tidak cacat dan sesuai dengan spesifikasi. PT. Panarub Industry adalah sebuah industri pembuatan sepatu dengan berbagai macam model. Dalam proses produksinya, PT.Panarub Industry melakukan pengendalian kualitas dengan menetapkan batas maksimum toleransi kerusakan sebesar 5\%. Namun, dalam pengendalian kualitas tersebut, masih terdapat produk cacat. adapun presentasenya adalah di atas batas toleransi mencapai $80 \%$ antara lain adalah Sepatu yang tidak Merekat atau Open Bond 77,81\%, kotor 12,58\%, Lem Berlebih atau Overcement Assembly 9,25\% dan miring 0,36\%. Akar masalah yang terdapat pada kualitas sepatu model Swift Run antara lain adalah faktor mausia yaitu karyawan yang kurang kompeten dan tidak memahami SOP ,faktor material yaitu kualitas bahan baku yang menurun dan tidak menjakankan sistem FIFO pada ruang penyimpanan material dan faktor mesin yaitu kurangnya penjadwalan dan pengecekan mesin secara berkala sehingga menyebabkan mesin sering mengalami kerusakan dan kondisi mesin yang kotor.
\end{abstract}

Kata Kunci : Kualitas, PDCA, 5W1H, Sepatu SwitRun, Cacat

\section{PENDAHULUAN}

\subsection{Latar Belakang}

Industri sepatu di Indonesia telah mengalami kemajuan yang cukup berarti. Kondisi tersebut diawali dengan produsen sepatu dalam negeri yang pada umumnya merupakan industri kecil (home industri) dengan kualitas yang masih rendah, kini telah berkembang menjadi produsen sepatu berskala besar yang mampu memproduksi sepatu berstandar internasional. Dalam perkembangannya, persaingan dalam industri sepatu olah raga baik di tingkat dunia maupun pada tingkat nasional sangat kompetitif. Untuk selalu meningkatkan daya saing serta agar tetap terjaga kerja sama yang baik dengan pihak pemegang merek yang selama ini telah terjalin, maka perusahaan dituntut untuk senantiasa 
meningkatkan mutu produk serta meningkatkan efektifitas dan efisiensi proses produksinya.

Sebagai produsen sepatu berkualitas internasional, sudah tentu kualitas menjadi perhatian utama perusahaan agar setiap produk yang dihasilkan dapat memuaskan pemesan khususnya dan konsumen pada umumnya. kualitas adalah conformance to requirement yaitu sesuai dengan yang disyaratkan atau distandartkan.Suatu produk memiliki kualitas apabila sesuai dengan standart kualitas yang telah ditentukan. Standart kualitas meliputi bahan baku, proses produksi, dan produk jadi (Crosby, 1979).

Sesuai pedoman sasaran mutu PT. Panarub Industry bahwa produk dikatakan berkualitas apabila tercapainya kesesuaian antara produksi yang dihasilkan dengan rencana target standar atau sasaran mutu yang ditetapkan oleh perusahaan pada setiap awal produksi atau target defect kumulatif adalah tidak lebih dari 5\% dari jumlah produksi. Untuk menekan tingkat kerusakan produk dan mempertahankan kualitas perlu pengedalian kualitas secara berlapis.

\subsection{Identifikasi Masalah}

Sasaran Mutu PT Panarub adalah total defect untuk product swift run haruslah di bawah 5\%, dengan sasaran mutu yang ditetapkan oleh perusahaan maka diperlukan perbaikan kualitas untuk mencapai target tersebut.

\subsection{Rumusan Masalah}

Adapun rumusan masalah yang terdapat dalam penelitian ini adalah, Jenis Defect dan berapa presentasinya yang ada pada Sepatu model Swift Run, serta Apa akar masalah atau penyebab dari defect Sepatu model Swift Run.

\subsection{Tujuan Penelitian}

Adapun tujuan dan manfaat yang ingin dicapai dari penelitian ini adalah untuk mengetahui jenis-jenis defect dan presentasinya yang terdapat pada produk sepatu model Swift Run serta mengetahui langkah atau tindakan apa yang harus diambil untuk mengatasi masalah ini di PT. Panarub Industry.

\section{METODOLOGI}

Penelitian ini dilakukan di PT. Panarub Industry. Data yang diambil pada penelitian ini adalah jumlah Produksi sepatu modelSwift Run, jumlah produk sepatu released dan jumlah sepatu yang defect. Subjek penelitian ini adalah produk sepatu model Swift Run. Penelitian menggunakan metode pendekatan PDCA (Plan-Do-Check-Action). Salah satu konsep problem solving yang diterapkan di tempat kerja menggunakan konsep PDCA yang diartikan sebagai proses penyelesaian dan pengendalian masalah dengan pola runtun dan sistematis. perbaikan proses secara terus menerus untuk selalu meningkat mutu dan produktivitas output.

\section{HASIL DAN PEMBAHASAN}

Dalam penelitian ini akan di jelaskan mengenai proses produksi,mesin dan proses PDCA dimana tujuan dari penelitian ini adalah akan di lakukan analisa untuk produk sepatu Swift Run. Sebelum masuk dalam tahap tahap yang dilakukan pada proses produksi model Swift Run untuk menekan defect yang terjadi perlu diketahu bahwa proses ini dilakukan di area Assembling Bullding A cell 8. 


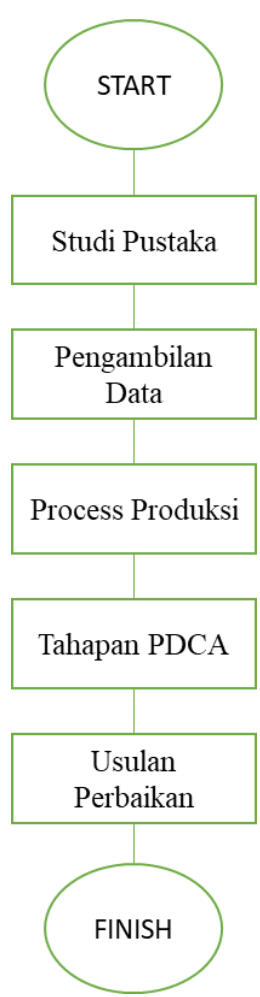

Gambar 1 Diagram Alir Penelitian

\subsection{Proses produksi}

Assembling merupakan proses menyatukan seluruh komponen pembentuk sepatu, dalam hal ini upper dan outsole. Assembling merupakan tahapan terakhir dalam serangkaian proses yang ada di CSA. Adapun alur proses produksi assembling, yaitu sebagai berikut:

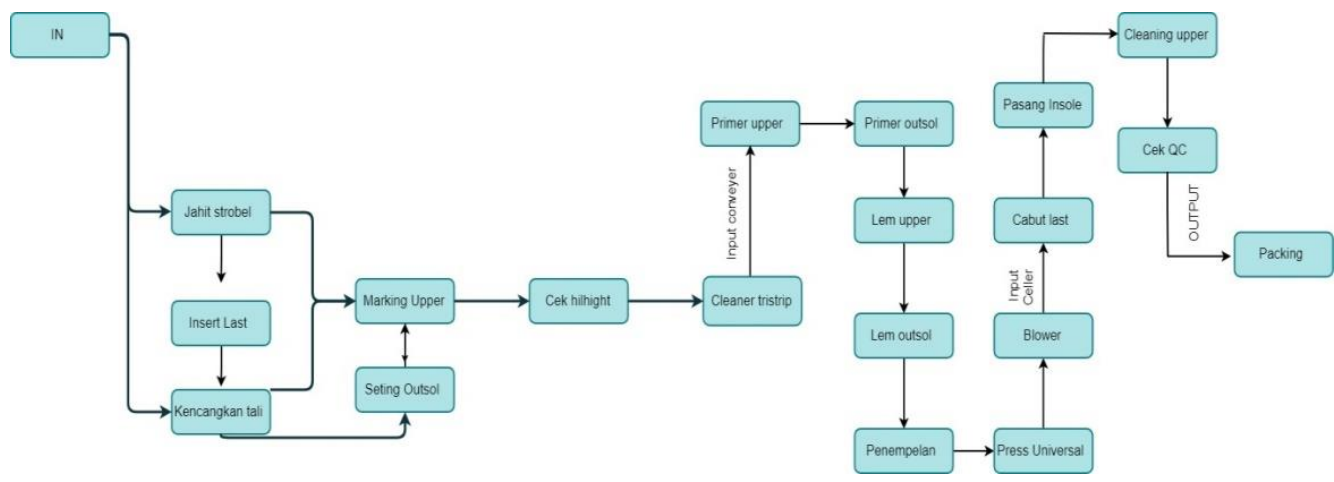

Gambar 2 Diagram Alir Proses Produksi Bagian Assembling

\subsection{PDCA}

Siklus PDCA yang terdiri dari 4 tahap (Plan, Do, Check, dan Action) merupakan program perbaikan atau peningkatan mutu produksi. Aplikasi siklus PDCA yang terbagi menjadi empat tahap (Plan, Do, Check, Action) tersebut digunakan dalam menganalisis permasalahan WIP produk sepatu mode Swift Run yang sedang terjadi di PT.Panarub Industry.

Plan adalah Penetapan target untuk perbaikan dan perumusan rencana tindakan atau kegiatan-kegiatan yang akan dilakukan guna mencapai target tersebut. Tindakan 
pertama dalam rencana perbaikan di PT Panarub Industry adalah mengumpulkan data sampel berupa jumlah produksi,jumlah cacat, dan jenis jumlah cacat dari pencatatan check sheet yangdilakukan oleh PT Panarub Industry. Data sampel yang akan di gunakan adalah data produksi dan data kecacatan pada produk sepatu model Swift Run. Data sempel yang akan digunakan adalah data produksi dan data kecacatan produk sepatu model Swift Run pada priode Februari sampai April 2019.

Data-data yang dikumpulkan dari perusahaan PT. Panarub Industry mengenai pengendalian kualitas data produksi dan data cacat pada produk sepatu model Swift Run. Data-data yang dikumpulkan 3 bulan terakhir yaitu bulan februari sampai april 2019. PT. Panarub Industry mengkategorikan produk yang tidak memenuhi spesifikasi kedalam beberapa macam jenis cacat diantaranya adalah :

1. Kotor

2. Miring

3. Lem Berlebih atau Overcement Assembly

4. Sepatu yang tidak Merekat atau Open Bond

jumlah cacat yang terjadi bertujuan untuk mengetahui seberapa banyak jumlah produk cacat selama dilakukan penelitian untuk mengetahui nilai cacat apa yang paling tinggi untuk diperbaiki. Berdasarkan data pengamatan yang diperoleh di PT. Panaru Industry, dapat dilihat bahwa data cacat yang terjadi pada Sepatu model Swift Run dapat dilihat pada Tabel di bawah ini. 
Tabel 1 Jenis cacat sepatu model Swif Run

\begin{tabular}{|c|c|c|c|c|c|c|}
\hline \multirow{2}{*}{ No. } & \multirow{2}{*}{ Tgl/Bulan } & \multirow{2}{*}{$\begin{array}{c}\text { Jumlah } \\
\text { Produksi (Prs) } \\
\end{array}$} & \multicolumn{4}{|c|}{ Jenis Cacat } \\
\hline & & & Kotor & Miring & Overcement & Openbond \\
\hline 1 & 01-Feb-19 & 1.200 & 44 & 2 & 12 & 125 \\
\hline 2 & 04-Feb-19 & 1.205 & 56 & 1 & 33 & 100 \\
\hline 3 & 06-Feb-19 & 1.110 & 19 & 0 & 11 & 191 \\
\hline 4 & 07-Feb-19 & 1.200 & 29 & 0 & 20 & 107 \\
\hline 5 & 08-Feb-19 & 1.200 & 34 & 0 & 17 & 99 \\
\hline 6 & 11-Feb-19 & 1.065 & 22 & 2 & 23 & 174 \\
\hline 7 & 12-Feb-19 & 1.200 & 43 & 4 & 22 & 170 \\
\hline 8 & 13-Feb-19 & 1.200 & 59 & 0 & 19 & 165 \\
\hline 9 & 14-Feb-19 & 1.200 & 14 & 0 & 40 & 69 \\
\hline 10 & 15-Feb-19 & 1.080 & 13 & 0 & 23 & 72 \\
\hline 11 & 18-Feb-19 & 1.180 & 16 & 0 & 18 & 153 \\
\hline 12 & 19-Feb-19 & 1.200 & 66 & 0 & 56 & 179 \\
\hline 13 & 20-Feb-19 & 1.200 & 32 & 1 & 13 & 154 \\
\hline 14 & 21-Feb-19 & 1.200 & 17 & 0 & 66 & 94 \\
\hline 15 & 22-Feb-19 & 1.165 & 14 & 2 & 51 & 59 \\
\hline 16 & 25-Feb-19 & 1.175 & 37 & 0 & 33 & 38 \\
\hline 17 & 26-Feb-19 & 1.200 & 18 & 0 & 21 & 85 \\
\hline 18 & 27-Feb-19 & 1.200 & 39 & 0 & 23 & 111 \\
\hline 19 & 28-Feb-19 & 1.200 & 14 & 6 & 43 & 103 \\
\hline 20 & 01-Mar-19 & 1.350 & 35 & 4 & 11 & 90 \\
\hline 21 & 02-Mar-19 & 1.115 & 19 & 0 & 45 & 90 \\
\hline 22 & 04-Mar-19 & 1.160 & 32 & 0 & 17 & 72 \\
\hline 23 & 06-Mar-19 & 1.200 & 10 & 4 & 10 & 77 \\
\hline 24 & 08-Mar-19 & 1.320 & 17 & 2 & 14 & 85 \\
\hline 25 & 11-Mar-19 & 1.200 & 77 & 2 & 17 & 49 \\
\hline 26 & 12-Mar-19 & 1.300 & 33 & 2 & 10 & 106 \\
\hline 27 & 13-Mar-19 & 1.180 & 51 & 0 & 32 & 54 \\
\hline 28 & 14-Mar-19 & 1.200 & 29 & 0 & 25 & 78 \\
\hline 29 & 15-Mar-19 & 1.200 & 21 & 0 & 26 & 120 \\
\hline 30 & 18-Mar-19 & 1.200 & 10 & 1 & 41 & 137 \\
\hline 31 & 19-Mar-19 & 1.190 & 14 & 3 & 25 & 79 \\
\hline 32 & 20-Mar-19 & 1.180 & 33 & 1 & 35 & 119 \\
\hline 33 & 21-Mar-19 & 1.320 & 14 & 0 & 27 & 103 \\
\hline 34 & 22-Mar-19 & 1.200 & 14 & 0 & 22 & 88 \\
\hline 35 & 25-Mar-19 & 1.310 & 28 & 0 & 34 & 63 \\
\hline 36 & 26-Mar-19 & 1.300 & 42 & 0 & 46 & 67 \\
\hline 37 & 27-Mar-19 & 1.000 & 46 & 0 & 44 & 89 \\
\hline 38 & 28-Mar-19 & 1.200 & 29 & 1 & 22 & 76 \\
\hline 39 & 29-Mar-19 & 1.200 & 65 & 4 & 26 & 109 \\
\hline 40 & 01-Apr-19 & 1.200 & 16 & 2 & 33 & 187 \\
\hline 41 & 02-Apr-19 & 1.250 & 32 & 1 & 34 & 134 \\
\hline 42 & 04-Apr-19 & 1.288 & 47 & 0 & 24 & 149 \\
\hline 43 & 05-Apr-19 & 1.200 & 64 & 0 & 11 & 76 \\
\hline 44 & 08-Apr-19 & 1.120 & 66 & 2 & 34 & 87 \\
\hline 45 & 09-Apr-19 & 1.200 & 95 & 0 & 11 & 88 \\
\hline 46 & 10-Apr-19 & 1.200 & 71 & 1 & 44 & 94 \\
\hline 47 & 11-Apr-19 & 1.200 & 58 & 0 & 22 & 110 \\
\hline 48 & 12-Apr-19 & 1.300 & 63 & 0 & 29 & 124 \\
\hline 49 & 15-Apr-19 & 1.144 & 22 & 0 & 66 & 113 \\
\hline 50 & 16-Apr-19 & 1.200 & 43 & 0 & 11 & 85 \\
\hline 51 & 17-Apr-19 & 1.200 & 46 & 3 & 15 & 134 \\
\hline 52 & 18-Apr-19 & 1.200 & 32 & 0 & 33 & 186 \\
\hline 53 & 22-Apr-19 & 1.120 & 33 & 2 & 19 & 174 \\
\hline 54 & 23-Apr-19 & 1.125 & 22 & 1 & 66 & 117 \\
\hline 55 & 24-Apr-19 & 1.225 & 45 & 0 & 22 & 88 \\
\hline 56 & 25-Apr-19 & 1.200 & 19 & 0 & 11 & 98 \\
\hline 57 & 26-Apr-19 & 1.200 & 40 & 5 & 20 & 118 \\
\hline 58 & 29-Apr-19 & 1.200 & 63 & 3 & 44 & 113 \\
\hline 59 & 30-Apr-19 & 1.250 & 65 & 0 & 43 & 102 \\
\hline
\end{tabular}

JIM, Vol. 5, No. 1, Februari 2020, pp.34-45 
Tabel 2 Data Jumlah Produksi dan Jumlah Cacat Sepatu Swift Run Bulan Februari April 2019

\begin{tabular}{|c|c|c|c|c|}
\hline Bulan & $\begin{array}{c}\text { Jumlah } \\
\text { Produksi } \\
\text { (Prs) }\end{array}$ & Jumlah Ok & $\begin{array}{c}\text { Jumlah Cacat } \\
\text { (Prs) }\end{array}$ & $\begin{array}{c}\text { Persentase } \\
\text { Cacat (\%) }\end{array}$ \\
\hline Februari & 22.380 & 19.134 & 3.366 & 15,04 \\
\hline Maret & 24.325 & 21.532 & 2.923 & 12,02 \\
\hline April & 24.022 & 20.192 & 3.830 & 15,94 \\
\hline Total & 70.727 & 60.858 & 10.119 & 18,078 \\
\hline
\end{tabular}

Hasil dari pengamblian data produksi dengan, ditemukan ketidaksesuaian antara sasaran mutu PT. Panarub Industry dengan actual produksi, dimana produk dikatakan berkualitas apabila tercapainya kesesuaian antara produksi yang dihasilkan dengan rencana target standar/sasaran mutu yang ditetapkan oleh perusahaan pada setiap awal produksi atau target defect kumulatif adalah tidak lebih dari 5\% dari jumlah produksi. Untuk menekan tingkat kerusakan produk dan mempertahankan kualitas perlu pengedalian kualitas secara berlapis

DO adalah pelaksanaan kegiatan-kegiatan dari rencana yang telah dilakukan untuk mencapai target tersebut. Pada tahapan ini akan di lakukan penetapan dan mengklarifikasikan dengan jumlah defect yang terjadi meggunakan Diagram Pareto dan Peta kendali p.Pada tahapan DO dilakikan pengelompokan data secara detail terkait data produksi,

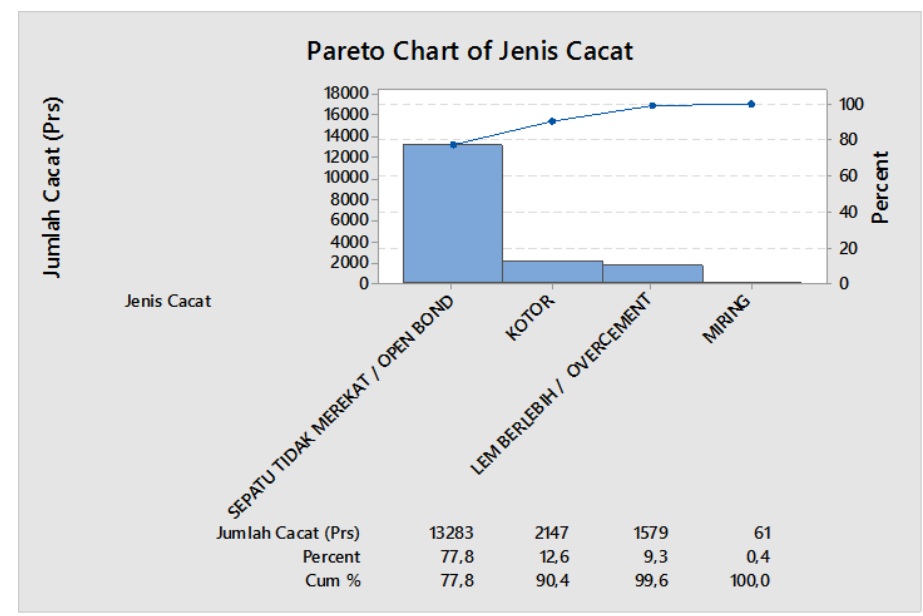

Gambar 3 Diagram Pareto

Dari hasil pengecekan diagram pareto jenis cacat paling besar terjadi pada jenis cacat yang disebabkan oleh sepatu tidak merekat (Open Bond) yaitu dengan jumlah persentase sebanyak $77,81 \%$ kemudian diikuti dengan cacat sepatu kotor sebesar $12,58 \%$ cacat lem berlebih (Overcement) sebesar 9,25\% sedangkan jenis cacat yang paling kecil terjadi dikarenakan cacat sepatu miring dimana jumlah persentase cacat yang dihasilkan yaitu $0,36 \%$.Setelah dibuat diagram pareto selanjutnya adalah melihat defect yang terjadi menggunakan peta kendali $\mathrm{p}$.

Pengendali proporsi kesalahan (p-chart) dan banyaknya kesalahan (np-chart) digunakan untuk mengetahui apakah cacat produk yang dihasilkan masih dalam batas yang disyaratkan. Perbandingan antara banyaknya cacat dengan semua pengamatan, yaitu setiap produk yang diklasifikasikan sebagai "diterima" atau "ditolak" (yang diperhatikan banyaknya produk cacat).Peta kendali p untuk melihat apakah proses pengendalian kualitas yang selama ini dilakukan oleh PT.Panarub Industry sudah terkendali atau tidak. 


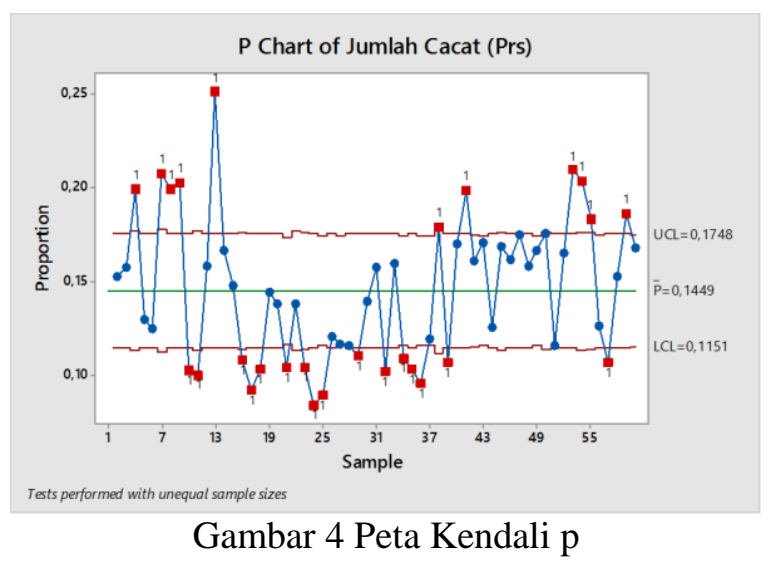

Berdasarkan gambar peta kendali p diatas dapat dilihat bahwa data yang diperoleh tidak seluruhnya berada dalam batas kendali yang telah ditetapkan bahkan banyak yang keluar dari batas kendali, sehingga bisa dikatakan bahwa proses tidak terkendali. Hal ini menunjukkan terjadi penyimpangan yang tinggi. Hal tersebut menyatakan bahwa pengendalian kualitas di PT.Panarub Industry Bullding A C8 memerlukan adanya perbaikan. Karena adanya titik berfluktuasi sangat tinggi dan tidak beraturan yang menunjukkan bahwa proses produksi masih mengalami penyimpangan.

Pada tahapan Check, kegiatan pemeriksaan hasil dari segala prosedur yang telah dijalankan guna memastikan agar tetap berjalan sesuai rencana sekaligus memantau kemajuan dari kegiatan yang telah ditempuh.Setelah melakukan beberapa tindakan pada tahap DO, maka langkah selanjutnya adalah memeriksa kembali apakah tindakan perbaikan tersebut dapat mengurangi jumlah kecacatan produk pada sepatu model Swift Run pada pengecekan ini dilakukan menggunakan Diagram Fishbone dan peta kendali $p$ yang dihilangkan.

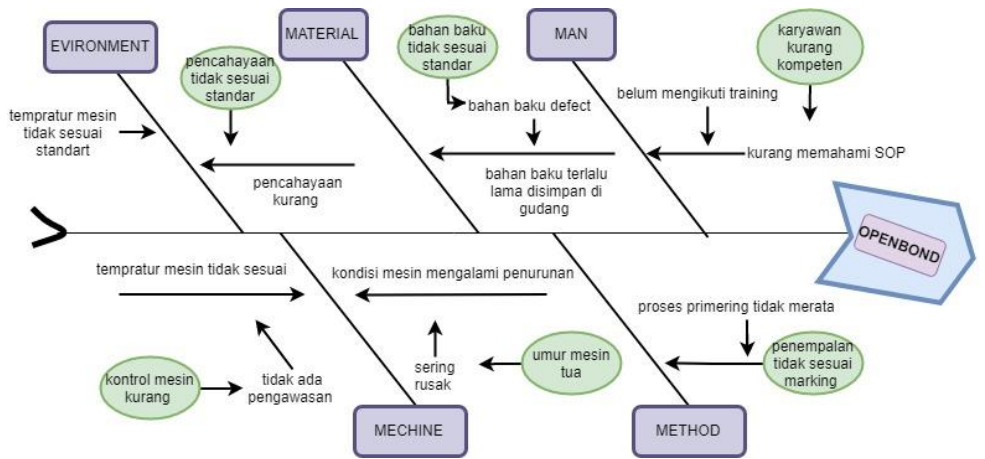

Gamar 5 Fishbone Diagram Openbond

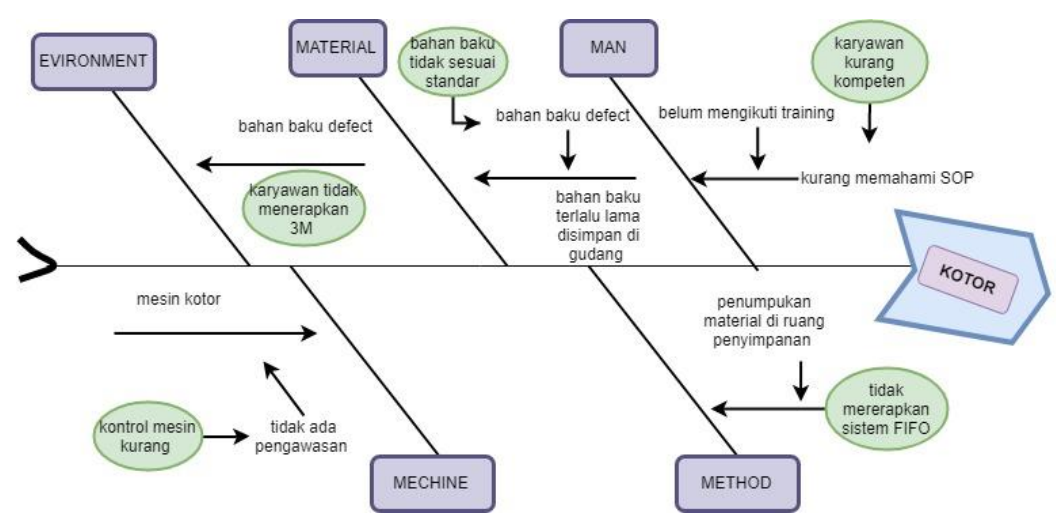

JIM, Vol. 5, No. 1, Februari 2020, pp.34-45 
Gamar 6 Fishbone Diagram Kotor

Dari gambar 5 dan 6 yaitu fishbone diagram openbond dan kotor dapat dijelaskan beberapa faktor yang mempengaruhi tingginya cacat Open Bond pada produk Sepatu Model Swift Run.

1. Manusia atau Man.

Karyawan kurang kompeten, Hal ini disebabkan karena karyawan yang baru belum diberikan sejumlah training mengenai proses penempelan sepatu. Karyawan Kurang Memahami SOP, Hal ini disebabkan karena dari pihak manajemen tidak ada sosialisasi ke karyawan tentang adanya pembaharuan SOP.

2. Mesin atau Machine

Kondisi mesin mengalami penurunan kinerja, Hal ini disebabkan karena kurang disiplinnya jadwal preventive maintenance sehingga part mesin tidak terawat optimal, mesin hanya diperbaiki saat mesin rusak. Temperatur mesin oven tidak sesuai standar Kurangnya pengawasan terhadap mesin yang menyebabkan temperature mesin oven yang tidak terkendali. Mesin kotor kurangnya perawatan pada mesin

3. Bahan Baku atau Material

Kualitas lem menurun yang disebabkan karena sedang terjadi trouble pada supplier.Raw material tidak sesuai standar mengalami defect (kotor) yang disebabkan karena penyimpanan terlalu lama di gudang dan tidak menerapkan sistem FIFO.

Dari data sebelumnya dapat dilihat bahwa masih banyak data yang tidak seluruhnya berada dalam batas kendali yang telah ditetapkan bahkan banyak yang keluar dari batas kendali. Karena penyebab keluarnya data dari batas pengendalian dianggap sebagia penyebab khusus (assignable cause) maka data tersebut di anggap out of statistical control yang harus di revisi.

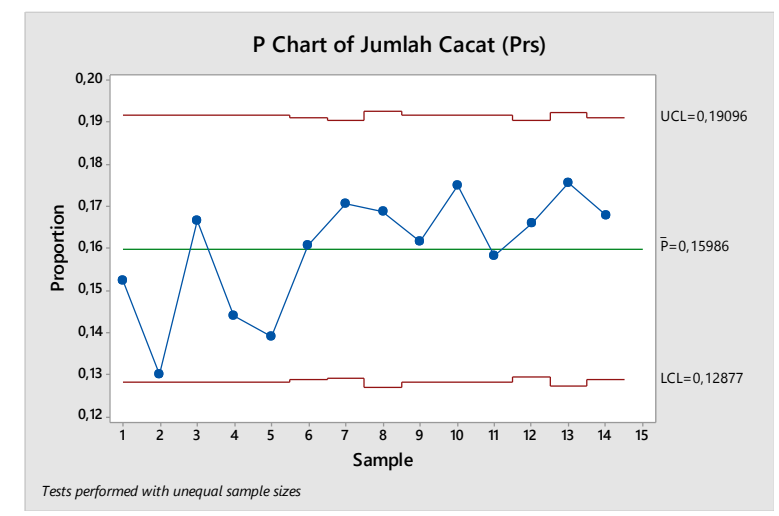

Gambar 7 Peta Kendali p yang di revisi

Setelah menghilangkan beberapa data yang upnormal maka dapat dilihat dari gambar di atas bahwa produksi Swift Run dapat stabil dalam control chart setelah menghilangkan data yang tidak beraturan. Dapat di lihat bahwa ada 45 hari yang upnormal dari 59 hari dalam memproduksi sepatu SwiftRun.Sehingga mendapatkan 14 hari yang stabil. Dengan demikian seluruh data hasil penelitian dalam tiga bualan berada di dalam batas pengendalian yang menunjukkan bahwa data tersebut dalam kondisi instatistical control atau telah sesuai dengan standar pengendalian proses.

Pada Tahapan Action, untuk menindak lanjuti ketiga langkah yang ditempuh sekaligus memutuskan prosedur baru guna menghindari terjadinya kembali masalah yang sama atau menetapkan sasaran baru bagi perbaikan berikutnya. Langkah yang harus dilakukan selanjutnya adalah mempertahankan hasil pengendalian kualitas yang telah tercapai untuk mencegah terulangnya masalah yang sama dan lebih meminimalkan tingkat kecacatan produk pada kegiatan produksi selanjutnya dengan menetapkan standar bagi perusahaan. Pada penelitian proses analisis dengan menggunakan metode $5 \mathrm{~W} 1 \mathrm{H}$ ini 
bertujuan untuk memberikan usulan tindakan yang dapat dilakukan perusahaan, khususnya yang terjadi karena human factor agar dapat meningkatkan kualitas sepatu yang diproduksi. Usulan yang diberikan dapat dilihat dalam table di bawah ini.

Tabel 3 Metode 5W1H Faktor Manusia

\begin{tabular}{|c|c|c|c|}
\hline FAKTOR & JENIS & $5 \mathrm{~W}+\mathbf{1 H}$ & DESKRIPSI \\
\hline \multirow{6}{*}{$\begin{array}{l}\text { Karyawan } \\
\text { kurang } \\
\text { kompeten }\end{array}$} & Tujuan Utama & Apa (What) & Karyawan kurang komponten \\
\hline & $\begin{array}{l}\text { Alasan } \\
\text { Kegunaan }\end{array}$ & $\begin{array}{l}\text { Mengapa } \\
(W h y)\end{array}$ & $\begin{array}{ll}- & \text { Karyawan kurang memahami SOP } \\
- & \text { Karyawan belum mengikuti training } \\
\end{array}$ \\
\hline & Lokasi & $\begin{array}{l}\text { Dimana } \\
\text { (Where) }\end{array}$ & Dilaksanakan di PT. Panarub Industry Pada ruang produksi \\
\hline & $\begin{array}{l}\text { Urutan } \\
\text { (Sekuens) }\end{array}$ & Kapan (When) & $\begin{array}{l}\text { Pada Saat Proses Produksi tidak beroperasi atau tidak sedang } \\
\text { berjalan }\end{array}$ \\
\hline & Orang & Siapa $(W h o)$ & Semua operator yang bekerja \\
\hline & Metode & $\begin{array}{l}\text { Bagaimana } \\
(\text { How })\end{array}$ & Melakukan training minimal 3 bulan sekali \\
\hline
\end{tabular}

Tabel 4 Metode 5W1H Faktor Material

\begin{tabular}{|c|c|c|c|}
\hline FAKTOR & JENIS & $5 \mathrm{~W}+1 \mathrm{H}$ & DESKRIPSI \\
\hline \multirow{6}{*}{$\begin{array}{l}\text { Bahan } \\
\text { baku tidak } \\
\text { sesuai } \\
\text { standar }\end{array}$} & Tujuan Utama & Apa (What) & Bahan baku defect/kotor \\
\hline & $\begin{array}{l}\text { Alasan } \\
\text { Kegunaan }\end{array}$ & $\begin{array}{l}\text { Mengapa } \\
(W h y)\end{array}$ & Karna terlalu lama disimpan di tempat penyimpanan \\
\hline & Lokasi & $\begin{array}{l}\text { Dimana } \\
\text { (Where) }\end{array}$ & $\begin{array}{l}\text { Dilaksanakan di PT. Panarub Industry Pada ruang penyimpanan } \\
\text { material }\end{array}$ \\
\hline & $\begin{array}{l}\text { Urutan } \\
\text { (Sekuens) }\end{array}$ & Kapan (When) & Pada saat pertama kali raw material datang ke area penyimpanan \\
\hline & Orang & Siapa $($ Who $)$ & Semua operator yang bekerja di area gudang penyimpanan \\
\hline & Metode & $\begin{array}{l}\text { Bagaimana } \\
\text { (How) }\end{array}$ & $\begin{array}{l}\text { Melakukan pengecekan secara berkala terhadap material dan } \\
\text { gunakan material yang pertama kali datang (FIFO). }\end{array}$ \\
\hline
\end{tabular}

Tabel 5 Metode 5W1H Faktor Mesin

\begin{tabular}{|c|c|c|c|}
\hline FAKTOR & JENIS & $5+1 H$ & DESKRIPSI \\
\hline \multirow{6}{*}{$\begin{array}{l}\text { Kontrol } \\
\text { mesin } \\
\text { kurang }\end{array}$} & Tujuan Utama & Apa (What) & Mesin sering rusak \\
\hline & Alasan Kegunaan & $\begin{array}{l}\text { Mengapa } \\
(W h y)\end{array}$ & Karna tidak ada perawatan dan pengawasan \\
\hline & Lokasi & $\begin{array}{l}\text { Dimana } \\
\text { (Where) }\end{array}$ & Dilaksanakan di PT. Panarub Industry Pada area produksi \\
\hline & Urutan (Sekuens) & $\begin{array}{l}\text { Kapan } \\
\text { (When) }\end{array}$ & $\begin{array}{l}\text { Pada Saat Proses Produksi tidak beroperasi atau tidak sedang } \\
\text { berjalan }\end{array}$ \\
\hline & Orang & Siapa (Who) & Semua maintenence yang mengawasi mesin \\
\hline & Metode & $\begin{array}{l}\text { Bagaimana } \\
(\text { How })\end{array}$ & Melakukan pengecekan mesin secara rutin dan berkala \\
\hline
\end{tabular}


Tabel 6 Metode 5W1H Faktor Metodh

\begin{tabular}{|c|c|c|c|}
\hline FAKTOR & JENIS & $5 \mathrm{~W}+1 \mathrm{H}$ & DESKRIPSI \\
\hline \multirow{7}{*}{ Metodh } & $\begin{array}{l}\text { Tujuan } \\
\text { Utama }\end{array}$ & Apa (What) & $\begin{array}{ll}\text { - } & \text { Penempelan tidak sesuai marking } \\
\text { - } & \text { Tidak menerapkan sistem FIFO }\end{array}$ \\
\hline & \multirow{2}{*}{$\begin{array}{l}\text { Alasan } \\
\text { Kegunaan }\end{array}$} & \multirow{2}{*}{$\begin{array}{l}\text { Mengapa } \\
(W h y)\end{array}$} & Proses primering tidak merata dan tidak mengikuti marking \\
\hline & & & Penumpukan material di ruang penyimpanan \\
\hline & Lokasi & $\begin{array}{l}\text { Dimana } \\
\text { (Where) }\end{array}$ & Dilaksanakan di PT. Panarub Industry \\
\hline & $\begin{array}{l}\text { Urutan } \\
\text { (Sekuens) }\end{array}$ & Kapan (When) & $\begin{array}{l}\text { Pada Saat Proses Produksi tidak beroperasi atau tidak sedang berjalan } \\
\text { dan di ruang penyimpanan }\end{array}$ \\
\hline & Orang & Siapa $(W h o)$ & Pimpinan dan semua operator \\
\hline & Metode & $\begin{array}{l}\text { Bagaimana } \\
\text { (How) }\end{array}$ & $\begin{array}{ll}\text { - } & \text { Melakukan traing pada karyawan agar setiap karyawan } \\
\text { memhami setiap SOP yang ada } & \\
\text { - } & \text { Menerapkan sistem FIFO pada ruang penyimpanan }\end{array}$ \\
\hline
\end{tabular}

Tabel 7 Metode 5W1H Faktor Environment

\begin{tabular}{|c|c|c|c|}
\hline FAKTOR & JENIS & $5 W+1 H$ & DESKRIPSI ATAU TINDAKAN \\
\hline \multirow{7}{*}{ Environment } & $\begin{array}{l}\text { Tujuan } \\
\text { Utama }\end{array}$ & Apa $($ What $)$ & $\begin{array}{l}\text { Pencahayaan tidak sesuai standar } \\
\text { - } \quad \text { Karyawan tidak menerapkan 3M (jangan } \\
\text { menerima,membuat,dan memberi barang reject) }\end{array}$ \\
\hline & \multirow{2}{*}{$\begin{array}{l}\text { Alasan } \\
\text { Kegunaan }\end{array}$} & \multirow{2}{*}{$\begin{array}{l}\text { Mengapa } \\
(\text { Why) }\end{array}$} & Karna pencahayaan kurang \\
\hline & & & Karna tidak ada kesadaran dari karyawan \\
\hline & Lokasi & $\begin{array}{l}\text { Dimana } \\
\text { (Where) }\end{array}$ & $\begin{array}{l}\text { Dilaksanakan di PT. Panarub Industry Pada ruang } \\
\text { produksi }\end{array}$ \\
\hline & $\begin{array}{l}\text { Urutan } \\
\text { (Sekuens) }\end{array}$ & Kapan (When) & $\begin{array}{l}\text { Pada Saat Proses Produksi tidak beroperasi atau tidak } \\
\text { sedang berjalan }\end{array}$ \\
\hline & Orang & Siapa $($ Who $)$ & Pimpinan dan semua operator produksi \\
\hline & Metode & $\begin{array}{l}\text { Bagaimana } \\
(\text { How })\end{array}$ & $\begin{array}{l}\text { - Melakukan pengecekan lampu } \\
\text { - Menerapkan sistem FIFO } \\
\text { - Menjalankan sistem 3M }\end{array}$ \\
\hline
\end{tabular}

Hasil analisa $5 \mathrm{~W} 1 \mathrm{H}$ yang yang telah dilakukan pada table di atas bahwa terdapat faktor penyebab terjadinya open bond dan kotor pada sepatu model Swift Run di antaranya adalah faktor manusia,faktor material dan faktor mesin. Pada faktor manusia terdapat dua hasil analisa yaitu Melakukan pelatihan kerja, pelatihan kedisiplinan, mengadakan penyuluhan akan pentingnya kualitas untuk setiap proses produksi sepatu.Melakukan Improvement Quality dengan cara Countinous Improvement Product and Quaility Melakukan pengambilan sampel.Pada faktor material terdapat dua analisa yaitu Melakukan pengecekan secara berkala terhadap material dan gunakan material yang pertama kali datang (FIFO).Dan pada faktor mesin terdapat dua analisa Melakukan pengecekan mesin secara rutin dan mengontrol suhu sesuai dengan standar yang telah di tetapkan.

Adapun tindakan-tindakan yang diperlukan untuk memperbaiki dan meningkatkan kualitas pada kinerja proses secara berkesinambungan. 
Tabel 8 Usulan perbaikan

\begin{tabular}{|c|c|}
\hline Man & Melakukan training minimal 3 bulan sekali \\
\hline Material & $\begin{array}{c}\text { Melakukan pengecekan secara berkala terhadap material } \\
\text { dan gunakan material yang pertama kali datang (FIFO). }\end{array}$ \\
\hline Mesin & Menjadwalkan pengecekan mesin secara rutin dan berkala \\
\hline Methodh & $-\begin{array}{l}\text { Melakukan traing pada karyawan agar setiap karyawan } \\
\text { memhami setiap SOP yang ada }\end{array}$ \\
\hline
\end{tabular}

\section{SIMPULAN DAN SARAN}

Berdasarkan hasil penelitian menggunakan metode siklus PDCA di PT. Panarub Industry, maka kesimpulan yang diperoleh adalah jenis - jenis cacat yang terjadi pada produk sepatu model Swift Run adalah Lem Berlebih (Overcement), Sepatu yang tidak Merekat (Open Bond), Kotor, dan Sepatu miring. Data didapatkan bahwa jenis cacat produk sepatu model Swift Run yang paling tinggi adalah Sepatu Tidak Merekat (Open Bond) dan kotor mencapai lebih dari $80 \%$ dalam jangka waktu tiga bulan didapat jumlah persentase paling tinggi sampai yang terendah, sebagai berikut :

1. Sepatu yang tidak Merekat / Open Bond $\quad=77,81 \%$

2. Kotor $=12,58 \%$

3. Lem Berlebih / Overcement Assembly $=9,25 \%$

4. Miring = $=0,36 \%$

Akar masalah yang terdapat pada kualitas sepatu model Swift Run antara lain adalah faktor mausia yaitu karyawan yang kurang kompeten dan tidak memahami SOP ,faktor material yaitu kualitas bahan baku yang menurun dan tidak menjakankan sistem FIFO pada ruang penyimpanan material dan faktor mesin yaitu kurangnya penjadwalan dan pengecekan mesin secara berkala sehingga menyebabkan mesin sering mengalami kerusakan dan kondisi mesin yang kotor.

Perusahaan dapat mempertimbangkan menggunakan metode Pareto Diagram,Control Chart dan Fishbone Diagram untuk mengetahui jenis produk yang sering mengalami cacat produk atau defect tertinggi dan juga mengetahui faktor-faktor yang paling mempengaruhi menjadi penyebab terjadinya defect itu sendiri.

Adapun saran yang diberikan untuk perusahaan guna memperbaiki kualitas produk Sepatu model adalah sebagai berikut :

1. Dalam pembuatan produk sepatu model Swift Run pada setiap proses sebaiknya SPV terkait atau line leader segera memberikan pengarahan dan instruksi kerja dengan benar pada operator tentang metode-metode yang digunakan pada proses kerja guna meminimasi terjadinya kecacatan produk.

2. Sebaiknya Supervisor Produksi menambahkan assisten leader untuk membantu meringankan beban kerja line leader serta untuk membantu memantau jalannya proses produksi agar tidak terjadi penyimpangan-penyimpangan yang menyebabkan kecacatan produk.

3. Setelah membuat rencana perbaikan sebaiknya segera dilakukan implementasi atau penerapan di line produksi. Hal ini dimaksudkan untuk mengetahui apakah rencana perbaikan tersebut dapat mengurangi jumlah defect dan mencegah terulangnya masalah defect yang sama.

4. Melakukan Improvement Quality dengan cara Countinous Improvement Product and Quaility. Melakukan pengambilan sampel oleh Manager, Kepala Bagian, Supervisor, CI, dan QC sebanyak 20 sampel setiap harinya. Gunanya untuk memantau kualitas sepatu di Line tersebut. 


\section{DAFTAR PUSTAKA}

Darsono, 2013, Analisis Pengendalian Kualitas Produksi Dalam Upaya Mengendalikan Tingkat Kerusakan Produk di PT. Albata, Jurnal Ekonomi - Manajemen - Akuntansi Vol. 35 Oktober, Semarang.

Ferdiansyah, 20011, Usulan Perbaikan Kualitas Produk Penyangga Duduk Jok Sepeda Motor Dengan Pendekatan Metode Kaizen $(5 \mathrm{~W}+1 \mathrm{H})$ di PT. Eka Prasarana, Jurnal Manajemen Universitas Gunadarma, Vol. 2 No. 1, Juli, Depok. pp. 1 - 21.

Nasution, M. N.. 2005. Manajemen Mutu Terpadu. Bogor : Ghalia Indonesia.

Nasution, S.R \& M, Dinda.R, 2011, Perbaikan Kualitas Dengan Metode PDCA untuk mengurangi cacat Frame Assembly Actuator Pada Proses Frame Assembly di PT.SJCI, Pusat Pengabdian Kepada Masyarakat Fakultas Teknik Universitas Pancasila, Vol. 24 No. 2, 2 Juni, Jakarta. pp. 70 - 74.

Prasetyawati, Meri, 2014, Pengendalian Kualitas Dalam Upaya Menurunkan Cacat Appearance Dengan Metode PDCA di PT. Astra Daihatsu Motor, Seminar Nasional Sains dan Teknologi, Fakultas Teknik Universitas Muhammadiyah Jakarta, November, Jakarta. 